\title{
O precariado e a luta de classes
}

The Precariat and Class Struggle

Le précariat et la lutte de classes

\section{Guy Standing}

Tradutor. João Paulo Moreira

\section{(2) OpenEdition}

\section{Journals}

\section{Edição electrónica}

URL: http://journals.openedition.org/rccs/5521

DOI: $10.4000 /$ rccs.5521

ISSN: 2182-7435

\section{Editora}

Centro de Estudos Sociais da Universidade de Coimbra

\section{Edição impressa}

Data de publição: 1 Maio 2014

Paginação: 9-24

ISSN: 0254-1106

\section{Refêrencia eletrónica}

Guy Standing, "O precariado e a luta de classes », Revista Crítica de Ciências Sociais [Online]

103 | 2014, colocado online no dia 26 maio 2014, criado a 19 abril 2019. URL : http:// journals.openedition.org/rccs/5521 ; DOI : 10.4000/rccs.5521 


\section{GUY STANDING}

\section{O precariado e a luta de classes}

A economia mundial encontra-se em plena Transformação Global, produzindo uma nova estrutura de classes a nível global. Está a surgir uma nova classe - o precariado -, que se caracteriza por incerteza e insegurança crónicas. Embora o precariado esteja ainda em constituição, com divisões no seu seio, os seus elementos encontram-se unidos na rejeição das velhas tradições políticas dominantes. Para se tornar uma classe transformadora, no entanto, o precariado necessita de ultrapassar o estádio de rebelião primária manifestado em 2011 e de se constituir como uma classe-para-si, capaz de se assumir como força de mudança. Isto implica uma luta pela redistribuição dos bens fundamentais para uma vida boa numa sociedade boa no século XXı - não os "meios de produção", mas a segurança socioeconómica, o controlo sobre o tempo, espaços de qualidade, conhecimento (ou instrução), saber financeiro e capital financeiro.

Palavras-chave: bem-estar social; economia mundial; estrutura de classes; precariedade laboral; segurança económica.

Toda a formação social produz a sua própria estrutura de classes, mesmo quando esta se vem acrescentar a estruturas anteriores. Encontramo-nos hoje em plena Transformação Global, análoga à Grande Transformação de Karl Polanyi (Polanyi, [1944] 2001). Neste caso, contudo, estamos a viver a construção dolorosa de um sistema de mercado global, ao passo que aquilo sobre que Polanyi escreveu tinha a ver com a criação de uma economia de mercado nacional e com as instituições que permitem "incrustar" a economia na sociedade.

Enquanto no início do século xx o proletariado - núcleo, então em expansão, da classe operária - estava na vanguarda das transformações sociopolíticas, a partir da década de 1980 ele deixou de ter a dimensão, a força e a perspetiva progressista necessárias ao desempenho desse papel. Foi, durante muitas décadas, uma força positiva, mas chegou a uma situação de impasse em resultado do seu laborismo intrínseco, ao querer o maior número de pessoas possível com "empregos" e ao associar direitos sociais e económicos à prestação de trabalho. 
Em meados do século xx, o capital, os sindicatos e o mundo do trabalho em geral, bem como os partidos trabalhistas e social-democratas estiveram, todos eles, de acordo quanto à criação de uma sociedade e de um Estado-providência inspirados no laborismo, assentes numa maioria proletarizada, apostados no trabalho estável e em que houvesse uma ligação implícita entre trabalho e benefícios. Para o proletário, o grande objetivo era ter trabalho "decente" e melhor, não a fuga ao trabalho. A estrutura de classes correspondente a tal sistema era relativamente fácil de descrever, com uma burguesia - empregadores, gestores e quadros superiores assalariados oposta ao proletariado e formando assim, no seu conjunto, a espinha dorsal da sociedade.

Hoje em dia ganha forma, a nível global, uma estrutura de classes profundamente diferente. Em resumo, e tal como a descrevo noutro local (Standing, 2009, 2011), ela é constituída por sete grupos, nem todos constituindo propriamente classes, quer na aceção marxista, quer no sentido weberiano do termo. Na sua maior parte possuem claras relações de produção, de distribuição, relações com o Estado e ainda uma clara consciência moral.

Abaixo dos grupos que podemos designar como classes existe uma subclasse, um lumpen-precariado constituído por gente que se arrasta, acabrunhada, pelas ruas, morrendo na miséria. Atendendo a que estão, de facto, excluídos da sociedade, a que não têm capacidade de ação ou qualquer papel ativo no sistema económico para além de amedrontarem quem nele se encontra, podemos deixá-los de lado, não obstante alguns dos seus elementos poderem eventualmente ser ativados em alturas de protesto popular.

Embora as classes não se definam unicamente pelo rendimento, é possível agrupá-las por ordem decrescente de rendimento médio. No topo da estrutura há uma plutocracia - um punhado de super-cidadãos detentores de uma vasta riqueza, na sua maior parte obtida ilicitamente, e gozando de um enorme poder informal, parcialmente associado ao capital financeiro. Vivem desvinculados do Estado-nação, muitas vezes com passaportes de conveniência de vários países. Muito do poder que detêm é um poder de manipulação, seja através de agentes, do financiamento de políticos e de partidos ou da ameaça de tirar o seu dinheiro do país caso os governos não lhes façam a vontade.

Abaixo da plutocracia encontra-se uma elite com a qual aquela tem muito em comum, embora os membros dessa elite possuam nacionalidade definida. Os dois grupos funcionam como classe dominante efetiva, quase hegemónica no seu presente estatuto. Eles corporizam o Estado neoliberal, manipulando os políticos e os meios de comunicação, enquanto, 
por outro lado, as agências financeiras cuidam para que as regras se lhes mantenham favoráveis.

Logo abaixo está o salariado, grupo com segurança de emprego a longo prazo, salários elevados e amplas regalias ao nível da relação empresarial. Os seus membros ocupam as burocracias do Estado e os escalões mais elevados das grandes companhias. A chave para se entender a sua posição de classe está em que vão buscar ao capital, sob a forma de ações, uma fatia cada vez maior dos rendimentos e da sua segurança. Tal significa que os seus proventos poderão aumentar se os salários forem esmagados, caso isso, por sua vez, signifique que sobe a participação nos lucros e, com ela, o valor das suas remunerações. Esta é uma das razões pelas quais poderá ser enganador juntar numa única classe o salariado e os que lhe ficam por baixo.

Com a privatização do setor público e com o emprego a ser terceirizado e atirado para offshores tanto por empresas como por agências governamentais, o salariado tem vindo a diminuir e muitos dos seus membros receiam vir a cair no precariado, sobre o qual nos deteremos já adiante. O salariado vai continuar a diminuir na maioria dos países, mas mesmo assim continuará a existir, sendo uma espécie de "classe média" ${ }^{1}$ Uma grande parte dos seus membros nutre, claramente, a esperança de ascender à elite ou transitar para o grupo seguinte.

Chamei a este grupo o dos proficians. Em número cada vez maior, ganham a vida como consultores, "empresários" independentes e em atividades afins. Auferem rendimentos elevados, mas vivem no limite e numa constante exposição a riscos morais, infringindo muitas vezes a lei sem quaisquer reservas. Além de crescerem em número, é também cada vez maior a sua influência no discurso político e no imaginário popular. Seria estulto afirmar que integram uma classe trabalhadora una, uma vez que são, fundamentalmente, empresários que a si mesmos se vendem, ou seja, constituem uma força de trabalho verdadeiramente mercadorizada.

Abaixo, em termos de rendimento médio, situa-se o núcleo do velho proletariado, em rápido processo de retração em todo o mundo. Aquilo que dele resta irá perdurar, mas falta-lhe a força para fazer avançar ou impor a sua agenda no domínio político, ou sequer para assustar o capital com reivindicações. Os Estados-providência e os regimes dos chamados "direitos laborais" foram feitos para eles, mas não para os que se situam mais abaixo na estrutura de classes.

${ }^{1}$ O salariado ocupa uma posição de classe contraditória, no sentido que Erik Olin-Wright (1978) dá à expressão. No entanto, considero que hoje em dia ele não faz, propriamente, parte de uma classe trabalhadora, sendo claro que está mais do lado do capital. 
Este facto tem implicações inusitadas para a natureza da luta de classes durante o período que se avizinha. Ao longo do século xx o proletariado conheceu uma gradual desmercadorização do trabalho, devido à circunstância de uma parte dos seus rendimentos consistir em ganhos de capital em remunerações não salariais. A materialização mais importante deste fenómeno são os gigantescos fundos de pensões que premeiam os trabalhadores proletarizados pelos longos anos de "serviço" durante os quais investiram em mercados de capitais para obter fundos. O resultado disso é que se torna muito difícil imaginar o proletariado a ter um papel "revolucionário" ou transformador, atendendo ao modo como os seus representantes, e nomeadamente os sindicatos, cimentaram os seus interesses no interior do próprio capitalismo.

\section{Definição de precariado}

Seja como for, é logo abaixo na escala - falando ainda em termos de rendimento médio - que o precariado vai, rapidamente, ganhando forma. Alguns comentaristas reagiram ao conceito argumentando que a precariedade é uma condição social. É-o de facto, mas uma condição social não age, falta-lhe a capacidade de ação humana. O precariado é uma classe-em-construção. Podemos precisar melhor a sua definição. Contudo, e como adiante veremos, ele possui uma caraterística ímpar que vai fazer com que seja uma peça charneira na fase de reimplantação da Transformação Global e nas lutas que terão de ter lugar para que esta seja alcançada.

O precariado tem relações de produção bem definidas e este tem sido o aspeto mais acentuado pela maioria dos comentadores, apesar de não ser, efetivamente, o mais determinante para a sua compreensão. $\mathrm{O}$ trabalho desempenhado pelo precariado é, de sua natureza, frágil e instável, andando associado à casualização, à informalização, às agências de emprego, ao regime de tempo parcial, ao falso autoemprego e a esse novo fenómeno de massas chamado crowd-sourcing, sobre o qual nos debruçamos noutro local (Standing, 2014).

Todas estas formas de trabalho "flexível" têm vindo a crescer um pouco por todo o mundo. O que já não é tão visível é que, nesse processo, o precariado se vê obrigado a desempenhar uma proporção elevada e em crescimento de trabalho-para-trabalhar relativamente ao trabalho propriamente dito. Assim, ele acaba por se ver tão explorado fora do local de trabalho e do período laboral remunerado como quando se encontra no emprego dentro do horário normal. Esse é um fator que distingue o precariado do velho proletariado.

O capital global e o Estado que lhe defende os interesses têm necessidade de um precariado grande, razão pela qual este é uma classe-em-construção 
a não uma subclasse. Se, durante a Grande Transformação, o capital industrial nacional se propunha habituar o núcleo do proletariado a um trabalho e a uma vida de estabilidade, hoje o capital global pretende habituar o precariado a um trabalho e a uma vida de instabilidade. Esta diferença fundamental é motivo para crer que juntar o proletariado e o precariado numa única categoria seria coartar a reflexão analítica e a imaginação política.

O precariado tem também relações de distribuição bem definidas, na medida em que depende quase exclusivamente de salários nominais, estando normalmente sujeito a flutuações e não dispondo nunca de um rendimento seguro. Ao contrário do que, também neste aspeto, se passava com o proletariado do século xx, cuja insegurança no emprego podia estar coberta por medidas de proteção social, o precariado encontra-se exposto a uma incerteza crónica, tendo pela frente uma vida de desconhecidas incógnitas.

São, finalmente, bem definidas também as relações do precariado com o Estado, no sentido em que possui menos direitos do que todos os demais. De facto, o precariado carateriza-se por uma fundamental insegurança no que toca a direitos. Como se demonstra noutro local (Standing, 2014), esta é a primeira vez na história em que o Estado retira sistematicamente direitos aos seus próprios cidadãos. Há cada vez mais pessoas - e não apenas migrantes - a ser transformadas em "denegadas", limitadas no alcance e no aprofundamento dos respetivos direitos cívicos, culturais, sociais, políticos e económicos. É-lhes, cada vez mais, negado aquilo a que Hannah Arendt chamou "o direito a ter direitos", e que constitui a essência da verdadeira cidadania.

Este aspeto é crucial para se entender o precariado. A sua caraterística essencial é ser mendigo, pedinte, obrigado a depender de dádivas discricionárias e condicionais vindas não só do Estado, como também das agências e demais instituições de caridade privadas que operam em seu nome. Para se entender o precariado e a natureza da luta de classes que aí vem, este facto reveste-se de uma relevância maior do que a insegurança das relações de trabalho que o caraterizam.

Por último, um outro traço distintivo do precariado é a sua consciência de classe, traduzida num fortíssimo sentimento de privação relativa e de frustração quanto ao seu estatuto. Esta circunstância carrega consigo conotações negativas, mas ao mesmo tempo contém um elemento de transformação radical, que coloca o precariado numa posição intermédia entre "o capital" e "o trabalho". Está menos sujeito a sofrer de falsa consciência quando ocupado nos empregos que calha encontrar e isso, em parte, porque não o prende nenhum sentimento de lealdade nem de 
compromisso em relação a um e outro. O precariado vê o emprego como algo de instrumental, não como algo capaz de determinar toda uma vida. A alienação em relação ao trabalho é, em suma, um dado adquirido.

Acresce que esta é, historicamente falando, a primeira classe para a qual a regra é possuir um nível de habilitações superior ao tipo de trabalho a que os seus membros poderão aspirar ou que poderão ver-se obrigados a desempenhar. Tal facto faz com que a alienação seja mais facilmente reconhecível. No entanto, o desequilíbrio daqui resultante gera na pessoa uma profunda frustração no que diz respeito ao status, além da raiva própria de quem não sente que há um futuro e que a vida e a sociedade hão de conduzir a um estádio melhor.

Em termos de consciência, porém, podemos ver por que razão o precariado é a nova classe perigosa, já que recusa as velhas tradições políticas dominantes, rejeitando por igual o laborismo e o neoliberalismo, a social-democracia e a democracia cristã. Mas ela também é perigosa num outro sentido. Uma forma expedita de o dizer será afirmar que ela não é, de momento, uma classe-para-si, uma vez que se acha em guerra contra si mesma devido ao facto de padecer de três formas de privação relativa, cada uma delas definidora dos três tipos de precariado atualmente em tensão.

\section{Os três tipos de precariado}

O primeiro tipo é constituído por aqueles que acabam por se ver afastados das velhas comunidades e famílias da classe trabalhadora; na sua maioria sem instrução, são propensos a associar o seu sentimento de privação e frustração a um passado perdido, seja ele real ou imaginado. Por isso tendem a dar ouvidos às vozes populistas e reacionárias da extrema-direita, culpando o segundo e até mesmo o terceiro tipos de precariado pelos problemas com que se defrontam. São os atávicos, um grupo que tende a deixar-se atrair pelo carisma. Formam o segmento do precariado que presentemente está a ser levado para a extrema-direita (veja-se, por exemplo, Goodwin e Ford, 2014), em parte devido à falta de uma agenda progressista dirigida a eles e capaz de apelar às suas aspirações e não ao medo da insegurança.

O segundo tipo é constituído pelos migrantes e pelas minorias, que, por não terem presente nem um sítio a que chamem seu, vivem imbuídos de um forte sentimento de privação relativa. Damos-lhes a designação de nostálgicos. Politicamente tendem a ser relativamente passivos ou desprendidos, com exceção de um ou outro dia de raiva, em que alguma coisa que se lhes apresenta como uma ameaça direta acaba por fazer incendiar a fúria coletiva. Foi o que aconteceu nos bairros de lata dos arredores 
de Estocolmo no início de 2013, em Tottenham (Londres) em agosto de 2011 e noutros surtos de violência.

O terceiro tipo é formado pelos instruídos, que, por força do trabalho inconstante e da falta de oportunidade para impor uma narrativa às suas vidas, experimentam um sentimento de privação relativa e de frustração quanto ao respetivo status, uma vez que lhes falta um sentido de futuro. Vamos designá-los por boémios. No entanto, porque se trata da parte potencialmente transformadora do precariado, que o mesmo é dizer da nova vanguarda, abre-se a possibilidade de serem apelidados de progressistas.

Olhando com atenção para os três tipos, vê-se que, de um modo geral, rejeitam as agendas políticas dominantes do século Xx. O neoliberalismo é, para eles, anátema. Consideram moralista, e com razão, a área política conservadora/democrata-cristã, desprezando-a pelo pendor utilitarista e pelos gestos de aproximação ao salariado. E quanto à social-democracia e ao laborismo - que nada fizeram pelo primeiro setor do precariado, são hostis ao segundo e não agradam ao terceiro -, só o que resta do proletariado e os segmentos mais baixos do salariado acham neles alguma relevância.

Paradoxalmente - mas com justeza, atendendo a que nos encontramos no meio de uma crise resultante das falhas do projeto neoliberal -, os sociais-democratas à moda antiga perderam a base eleitoral e estão a ser mais afetados pelo crescimento do precariado do que qualquer outra corrente política. Os sociais-democratas parecem propor um regresso ao passado, sem perceberem que também quanto a isso o núcleo do precariado se encontra alienado.

Alguns sociólogos, como Richard Sennett (1998), pintam a imagem da perda de uma época áurea do capitalismo e parece quererem recriar aquilo que foi um passado laborista de cunho masculino, retratando a realidade atual como algo que "corrói o caráter", como se essa não fosse a eterna caraterística do capitalismo. Mas tal como, nos finais do século XIX, a classe perigosa eram aqueles que resistiam à proletarização (Jankiewicz, 2012), hoje em dia o precariado encontra-se, de facto, psicologicamente livre do laborismo, o que faz dele a atual classe perigosa. Isso mesmo foi esplendidamente expresso num graffiti subversivo desenhado por alguém do movimento dos indignados: "O pior seria voltar à velha normalidade."

O aspeto-chave a considerar é que existe no seio do precariado, sob várias formas, terreno comum para uma rejeição do velho consenso político e dos partidos do centro-direita e centro-esquerda. Daí a perceção de que se assiste a uma crise da democracia, pois o precariado não se sente representado e recusa entregar-se a uma realidade política mercadorizada e em plena perda. Quando os indignados da Puerta del Sol ostentam dizeres como "Me gustas 
democracia, pero estás como ausente”, a sua rejeição dos partidos políticos assume um caráter profundamente político (Estanque, 2013).

\section{O precariado enquanto classe transformadora}

O que se acaba de afirmar não permite, no entanto, concluir que o precariado é apolítico, já que ele é também, num outro sentido, a classe perigosa emergente. A sua tarefa imediata consiste em ultrapassar a fase de rebelião primária em que se encontrava em 2011 - a fase de saber a que é que se opõe, sem que no entanto seja, ainda, a classe-para-si capaz de se assumir como força de mudança.

Neste ponto há que ter cautela. Um dos trunfos do neoliberalismo foi ter atingido uma hegemonia linguística que lhe permitiu dominar o discurso político, económico e social, e inclusivamente o discurso cultural. Um desafio que hoje se coloca é o de reassumir a linguagem de maneira a criar, pela via da imaginação, um futuro desejável. Trata-se, nada mais nada menos, do que fazer renascer a própria ideia de futuro, perdida na distopia neoliberal do consumismo desenfreado e de uma existência plebeia de pão-e-circo eletrónico. As chamas da luta dissipar-se-ão rapidamente em dias de protesto vão se a luta se limitar a ser contra o que vai acontecendo.

Tem sido esta, de algum modo, a situação verificada com os protestos em massa ocorridos desde 2011, na sua grande parte semelhantes a uma série de fogos de artifício, que poderão ser espetaculares para os olhos e os ouvidos, mas logo se desvanecem em fumaça colorida. Esta fase de ansiedade coletiva não deixará seguramente, contudo, de evoluir no sentido de algo mais estratégico.

No seu esforço para inventar uma nova linguagem progressista assente na ação coletiva, o precariado deve evitar cair na bem montada armadilha que seria apresentar-se como "revolucionário", imagem decididamente maculada pela história do século xx. Deve também evitar, por estéril, a pose "reformista", que é o que o Estado gostaria que ele fosse, apostando em meros aprimoramentos superficiais do status quo. Para se tornar uma classe-para-si, o precariado tem de ser transformador.

Tem de ser transformador e, por conseguinte, perceber que, para inverter a tendência no sentido de maiores desigualdades, o sistema económico do mercado global exige um novo sistema de distribuição. Tem de se deixar, o mais possível, de usar o datado linguajar marxista do século XIX, sem contudo abandonar os valores emancipatórios que ao longo dos tempos guiaram os espíritos progressistas e igualitaristas, bem como as ideias igualitárias em torno da luta de classes.

Há um século, fazia sentido afirmar que o sistema de distribuição traduzia, de uma forma geral, o capital e o trabalho, os lucros e os salários, com 
o equilíbrio das forças sociais a determinar que parte do rendimento era atribuída ao trabalho, através da mediação do Estado pela via dos impostos, de subsídios e benefícios vários, bem como de toda uma estrutura de regulações que moldavam o poder de negociação relativo dos interesses de classe em confronto.

$\mathrm{Na}$ economia do mercado global, resta um só vencedor nesse velho modelo de distribuição. Em todos os cantos do globo, a parte do rendimento nacional correspondente aos salários caiu drasticamente, sendo muito pouco provável que volte a subir. Não obstante as atenções estarem sobretudo voltadas para a queda verificada nos EUA e na Europa, a verdade é que é principalmente nos gigantes emergentes da China e da Índia que a parcela do trabalho tem decaído mais.

É principalmente sobre o precariado que se têm abatido as consequências da queda contínua da massa salarial, ao passo que a elite, o salariado e o velho - e cada vez mais reduzido - núcleo do proletariado têm visto subir o respetivo rendimento social ou apenas sofrido ligeiras perdas, uma vez que passaram a receber uma porção maior desse rendimento sob a forma de capital, através de ações, opções sobre ações, bónus exorbitantes e receitas de rendas. Os países capitalistas avançados são hoje, cada vez mais, economias rentistas.

A mensagem deve ser clara. O precariado não deve alimentar a esperança de que os salários reais irão subir. Os salários vão continuar a descer nos países da OCDE, ainda que pontualmente se registem aumentos em alguns locais e para determinados grupos. A resposta laborista à crise da Transformação Global é mais "empregos" e salários mais altos, ao mesmo tempo que deposita fé nas campanhas por um rendimento mínimo digno ${ }^{2}$ e por um salário mínimo nacional. A verdade, porém, é que, para a maioria do precariado, os salários deixarão de proporcionar um padrão de vida digno. $\mathrm{O}$ foco da luta deve ser outro.

Num contexto laboral aberto e flexível, o mantra social-democrata de mais empregos e melhores salários faz lembrar a famosa história de Canuto o Grande, o rei viking que mandou que o levassem no trono até à praia, onde, sentado frente ao mar, ordenou às ondas que recuassem. Parece tê-lo feito para que os membros da corte entendessem os limites do seu poder. A versão mais popular da história é que mandar as ondas recuar é de quem está a pedir para se afogar. E é essa a situação em que o precariado, atualmente, se encontra. $\mathrm{O}$ emprego não leva senão a uma maior insegurança e à necessidade de um endividamento cada vez maior.

\footnotetext{
2 "Living wage" no original - o rendimento necessário para não só satisfazer as necessidades básicas, mas também manter um nível de vida digno. [N.T.]
} 
Em novembro de 2012 a Confederação Europeia de Sindicatos apelou a uma "greve geral" em toda a Europa, naquilo a que chamou um Dia Europeu de Ação e Solidariedade em defesa dos "empregos" e contra a austeridade. Os organizadores deviam saber perfeitamente que a iniciativa não iria ter, no plano imediato, o mínimo efeito sobre as políticas então em preparação. É provável que os animasse alguma esperança de que a mobilização pudesse deixar inquietos os responsáveis pelas políticas, levando-os a empreender mudanças mais tarde. Ou terá sido para mostrar que ainda tinham força para fazer sair à rua as multidões?

Quaisquer que fossem os propósitos, tratou-se de um apelo à piedade, feito por mendigos e em seu nome. Dai-nos mais trabalho subordinado em resposta ao nosso sofrer! Muitos dos que responderam à chamada oferecendo o seu tempo devem ter sentido que estavam a desperdiçar energias num gesto que em nada ameaçava as forças a que se opunham. Não se pode dizer que descer à rua para gritar slogans exigindo empregos a servir hambúrgueres ou a repor as prateleiras dos supermercados seja muito dignificante ou que constitua uma ameaça aos rentistas que beneficiam com a ordem do mercado global. Foi uma greve dos vencidos, não uma greve para avançar na marcha rumo a uma Sociedade Boa.

Com essa nova marcha em mente, o precariado terá de se bater por um novo sistema de distribuição assente no entendimento de que uma parcela crescente do rendimento total vai continuar a fluir principalmente para o capital financeiro e global e para a plutocracia e a elite, com o salariado a receber quanto baste para ir repartindo as suas lealdades.

Os países ricos, em particular, estão a transformar-se em economias rentistas, recebendo pelas suas atividades no mercado global uma porção cada vez maior do respetivo rendimento. Deste modo, a luta do precariado deverá centrar-se no desenvolvimento de mecanismos com vista a fazer com que o rendimento que atualmente vai para a plutocracia, a elite e o salariado passe a ser canalizado para o resto da população, incluindo o lumpen-precariado, mas sobretudo o precariado, que é efetivamente uma classe, a mais baixa e mais ativa.

Nessa luta por um novo sistema de distribuição, a atual tendência global no sentido da criação de fundos nacionais ou soberanos deve ser acelerada e submetida aos mecanismos da governação democrática. Hoje em dia são mais de 60 os países com fundos de capital nacional. De entre estes, apenas três funcionam como instrumentos de uma distribuição progressista - o Fundo Permanente do Alasca, o fundo norueguês e, um tanto surpreendentemente, o sistema iraniano. Quase todos os restantes funcionam como meios de enriquecimento de uma plutocracia e de uma elite já inchadas de 
tão gordas. O precariado tem de lutar para transformá-los em instituições democráticas de distribuição.

Repare-se na palavra. Porque o precariado tem de usar as palavras com critério. Assim, não deve deixar-se levar por falsas alternativas, como "pré-distribuição" - uma expressão manifestamente infeliz que conheceu uma popularidade breve na política inglesa, pela boca do responsável máximo do Partido Trabalhista. A expressão não significa nada em especial, a não ser o cuidado em evitar a dificuldade de defender a redistribuição.

O velho sistema de distribuição já não funciona segundo a antiga lógica, que consistia em fomentar o investimento e o trabalho através de efetivos incentivos. São demasiadas as armadilhas para se cair na pobreza (quando a troca dos magros benefícios do Estado por empregos de baixo salário significa uma taxa fiscal marginal de mais de $80 \%$ ) e as armadilhas da precariedade (que significa que os empregos de baixo salário se traduzem numa descida dos rendimentos no longo prazo). O precariado consegue entender tudo isto, ao passo que, para o velho proletariado, a reação seria de perplexidade. É por isso que os sindicatos têm mostrado tanta dificuldade em atrair e lidar com o precariado, e vice-versa.

Para os sociais-democratas, para outros laboristas e para os sindicatos, o caminho é exigir melhores salários e segurança no trabalho. Mas a criação de mais postos de trabalho não conseguirá responder à questão da distribuição. O precariado já aceitou este facto, quanto mais não seja para ganhar alguma paz de espírito. Os empregos a que os seus membros conseguirem aceder têm um mero caráter instrumental. Não são empregos para estruturar toda uma vida, nem empregos passíveis de conduzir, como outrora, a uma carreira, e muito menos a uma vida de segurança emancipatória.

\section{A luta pela redistribuição}

A luta pela redistribuição - mais do que por um novo sistema de distribuição - deverá ser reinterpretada, de maneira a desafiar intelectualmente os velhos partidos políticos. Assim, haverá que perguntar quais os bens ou ativos fundamentais em torno dos quais deve ser travada a luta de classes. Não, seguramente, os meios de produção, nem as "altas instâncias" do sistema de produção, que enformaram o projeto socialista e a luta de classes nos séculos XIX e XX. Eventuais menções a uma tomada das fábricas ou das minas iriam, certamente, dar azo a sorrisos e esgares de constrangimento em qualquer reunião do precariado.

Bens fundamentais serão aqueles que se afigurem necessários para alcançar uma vida boa numa sociedade boa, em que cada vez mais pessoas consigam perseguir a sua própria ideia de ocupação e em que o trabalho, 
o verdadeiro lazer e a reprodução possam florescer dentro de padrões flexíveis. Antes de ponderar quais possam ser esses bens, há um aspeto que é essencial para compreender a luta pela sua conquista.

Refiro-me à caraterística singular a que acima aludi. Se quiser ter a força que é necessária para, pela via da afirmação, se abolir a si próprio, o precariado terá de se tornar uma classe-para-si - ou então, uma parte suficiente dos seus membros terá de atingir um suficiente patamar de comunalidade. Isto faz dele uma classe verdadeiramente transformadora e, por isso, perigosa. Outras classes da atual distopia neoliberal têm uma natureza utilitária, pretendendo perpetuar-se e obter cada vez mais das estruturas existentes. São conservadoras, ou reacionárias, na medida em que se opõem a mudanças estruturais. Só o precariado está em posição de ser verdadeiramente transformador, para avançar na luta por aquilo a que Hannah Arendt chamou "o direito a ter direitos".

Quais os bens fundamentais pelos quais o precariado se deve bater? Resumindo o que já enunciei de maneira desenvolvida noutras obras (Standing, 2011, 2014), são eles a segurança socioeconómica, o controlo sobre o tempo, espaços de qualidade, conhecimento (ou instrução), saber financeiro e capital financeiro. Todos eles se encontram, presentemente, distribuídos de uma maneira desigual, e essa desigualdade está a tornar-se ainda mais pronunciada no que se refere ao controlo a que estão sujeitos. Pode mesmo afirmar-se que a distribuição de muitos desses bens é ainda mais desequilibrada do que a própria distribuição dos rendimentos. Por exemplo, enquanto a plutocracia, a elite, o salariado e, em certa medida, os proficians possuem meios para assegurar a sua própria segurança económica, o precariado encontra-se exposto a riscos elevados, sendo baixa a probabilidade de conseguir fazer face a esses riscos ou de vir a recuperar deles. Acima de tudo, confronta-se com a perspetiva de uma incerteza crónica. A distribuição da segurança económica é mais desigual do que a distribuição do rendimento (ILO, 2004).

Pelo menos na sua parte mais nuclear, o velho proletariado gozava de segurança no trabalho, uma vez que havia disposições de proteção social contra os riscos de desemprego, doença, velhice, acidentes, etc. Era uma forma manipuladora de segurança, porquanto era dada pelo Estado desde que o trabalhador acatasse a disciplina e os ditames do trabalho. Mas a trajetória do trabalhador assentava numa segurança que estava associada ao trabalho e em que os riscos a este também associados (acidente, doença, desemprego, etc.) se encontravam cobertos, de tal forma que os trabalhadores cumpridores e as famílias deles dependentes tinham sempre a perspetiva de direitos compensatórios (equivocamente chamados direitos laborais) 
em caso de adversidade. Era essa a norma e acalentava-se a perspetiva de que passasse a sê-lo também para muitos outros, ao ritmo do crescimento económico. Esta última expectativa já há muito que se desvaneceu.

Pelo contrário, o precariado tem pela frente a incerteza, uma vida de "desconhecidas incógnitas" sem sistema de segurança possível, porque, probabilisticamente falando, não há como calcular as hipóteses de as adversidades ocorrerem. Todos os aspetos da vida se revestem de incerteza. E quando algum mal acontece, não é certo que haja uma rede para servir de amparo. É por isso que, para o precariado, a regra é viver no fio da dívida crónica e insustentável. Atingir uma redistribuição da segurança é algo de fundamental para a luta que se avizinha.

Essa luta pela segurança abre a possibilidade de uma aliança transclassista, porquanto serão cada vez mais numerosos os membros de outros grupos a dar valor à necessidade - incluindo, muito provavelmente, a sua própria necessidade - de uma segurança mínima. Deste modo, eventuais políticas apostadas nesse mínimo de segurança poderão conseguir apelar para os escalões mais baixos da classe média, que vivem num medo cada vez maior de cair na precariado ou de que tal venha a suceder aos seus filhos.

Com respeito ao tempo enquanto bem ou ativo da vida, verifica-se que o precariado não tem controlo sobre o seu tempo e que os seus membros vivem num estado de permanente prontidão, que acorrem a atividades várias, ficam à espera que haja trabalho, realizam quantidades de trabalho ainda maiores quando a tal chamados, porque nunca sabem qual a forma melhor de gerir o tempo. Daí poder afirmar-se que o precariado padece do mal epidémico da mente precarizada, que o torna incapaz de se concentrar e o desvia de objetivos viáveis. O precariado precisa de políticas que lhe permitam assumir o controlo do seu próprio tempo. Precisamos de uma política do tempo.

Quanto à luta pela redistribuição de espaços de qualidade, ela tem o seu símbolo na luta para fazer reviver os commons. Trata-se, efetivamente, de uma metáfora, visto que traduz mais do que a luta pela preservação de terrenos públicos onde as pessoas se podem reunir. Ou seja, o seu significado estende-se àquilo que é social e culturalmente comum e também, em certo sentido, à esfera do politicamente comum.

A democracia deliberativa exige espaços públicos em que as queixas possam ser verbalizadas e partilhadas, conduzindo não a uma mera resistência, mas a propostas políticas e ao renascer da ação coletiva. A este propósito, o precariado carece de commons florescentes, não só para complementar a insuficiência dos rendimentos, mas para contrariar os discursos dominantes, veiculados por uma comunicação social que é manipulada pela plutocracia. 
De seguida há que considerar que, para o precariado, a luta pela redistribuição da instrução é um aspeto definidor da vida. Neste particular, o precariado terá de ultrapassar um certo sentimento de falsa consciência disseminado pelo próprio sistema educativo, opondo-se a uma retórica do "capital humano" que os neoliberais têm vindo a refinar. $\mathrm{Na}$ aparência, há hoje mais gente a melhorar o seu "nível" de instrução do que em qualquer outro período da história. No entanto, a verdadeira instrução está distribuída de maneira muito desigual e o que por aí se vende como instrução não passa, cada vez mais, de uma fraude. Enquanto os ricos têm acesso a uma educação que lhes permite dar asas ao espírito e ser inovadores, o precariado vê-se relegado para uma escolarização de "capital humano" mercadorizado, concebida para preparar os seus membros para o emprego e habituá-los a uma vida de trabalho instável e vivida com espírito plebeu.

A luta pela desmercadorização da educação é crucial se o precariado quiser atingir uma dimensão criativa, artística, subversiva e, em última análise, política e moral. E mais uma vez, refira-se que deve procurar alianças em setores do salariado e também entre os proficians, um grupo que é, por intuição, não conformista.

A luta por um saber financeiro visa capacitar o precariado para lidar eficazmente com questões financeiras. A estrutura fiscal da moderna sociedade de mercado é tremendamente complexa, permitindo que aqueles que têm acesso a especialistas de assuntos fiscais ganhem muitíssimo mais dinheiro, enquanto o "povo miúdo" acaba por pagar mais impostos do que devia. O direito ao saber financeiro e a serviços financeiros de natureza pública é mais importante do que muita gente pensa. O precariado não deveria tardar a mobilizar-se em torno da reivindicação de um direito universal à obtenção de saber financeiro. No contexto do endividamento pessoal crónico, causado por "tubarões agiotas" e empréstimos estudantis que duram anos e anos, esta deixou de ser uma questão menor.

Mais importante do que tudo será, talvez, a luta por uma repartição equitativa do capital financeiro, por via da instituição de um rendimento mínimo e da criação de fundos soberanos democráticos. Mas as diversas lutas aqui enumeradas deverão articular-se dentro de uma estratégia transformadora. Cada um destes elementos abre possibilidades de alianças transclassistas com um ou mais dos restantes grupos sociais. Porque a verdade é que é crescente a proporção dos salariados, dos proficians e dos trabalhadores do núcleo do velho proletariado a sentir-se tomados pelo medo - medo do fracasso, medo da perda. Há de chegar o momento em que, tendo feito "de todos nós cobardes", como disse Hamlet, o medo nos fará leões enraivecidos. 
Em muitos países o precariado sofreu uma enorme expansão em consequência do período de austeridade que se vive. Ao mesmo tempo, é também claro o seu amadurecimento. Em cada Grande Transformação, a luta desenvolve-se em três fases. A primeira é a fase dos "rebeldes primitivos", em que os elementos da classe emergente procuram o Reconhecimento, isto é, uma identidade comum. É isso que vem acontecendo, e de forma assinalável, desde 2011. Hoje, é da ordem dos milhões o número dos que continuam a descobrir um sentimento de identidade comum e a identificar-se como parte do precariado, sem vergonha e imbuídos de um sentimento de orgulho. Isso traz consigo uma unidade potencial, necessária a uma ação coletiva eficaz. Não sendo condição suficiente, é uma condição necessária.

A fase seguinte é a da luta pela Representação, por ter uma Voz coletiva e individual em todas as instâncias do Estado, pela capacidade de fazer barulho nos órgãos estatais, nos meios de comunicação social e nas redes do discurso público. É esta a fase que se aproxima. A subjetividade do precariado tem de ser afirmada, para que as burocracias deixem de poder tratar os seus membros como falhados que se mandam para a reforma, que se transformam em seres mais "empregáveis" ou que se castiga.

Como passo seguinte, o crescente acordar para o Reconhecimento coletivo e as iniciativas dos rebeldes primitivos e da resistência em massa devem dar lugar a um recomprometimento político. Isso está já a acontecer, ainda que de uma forma díspar, em entidades como o Partido X na Espanha, o Syriza na Grécia e o M5S na Itália. Em última análise, este fenómeno tem a ver com a repolitização, na ágora, da própria política, no momento em que o precariado reivindica passar de objeto a sujeito.

Assim, e por exemplo, os tumultos do Parque Gezi em Istambul e os exaltantes levantamentos ocorridos nas cidades brasileiras em 2013 podem, em certa medida, ser interpretados como uma reivindicação por uma democracia participativa mais inclusiva, em que o precariado passe a ter um real poder de ação coletiva e individual.

À medida que se for avançando em termos de Reconhecimento e de Representação, a luta por um novo sistema de distribuição e pela redistribuição do acesso aos bens fundamentais atrás enunciados começará a absorver as energias coletivas do precariado e respetivos aliados. Fundos de capital, rendimento mínimo para todos, comunidades ocupacionais, sindicatos e associações em novos moldes, e o mais que já se consegue entrever. O precariado está a ganhar forma. Como afirmou Shelley (1819) no maior poema de protesto político em língua inglesa, escrito numa época de agitação social comparável à nossa, há duzentos anos, e inspirado na 
repressão violenta, numa praça pública, da classe operária emergente, o precariado está a atingir o estádio em que se dará conta do poder que tem: "Sois vós muitos, e eles poucos!".

Tradução de João Paulo Moreira

Recebido a 10.10.2013

Aprovado para publicação a 26.02.2014

\section{Referências bibliográficas}

Estanque, Elísio (2013), "Social Movements and Middle-class Rebellion: An Essay on Recent Mass Protests" (mimeo).

Goodwin, Matthew; Ford, Robert (2014), Revolt on the Right: Explaining Public Support for the Radical Right in Britain. London: Routledge.

ILO - International Labour Organisation (2004), Economic Security for a Better World. Geneva: International Labour Organisation.

Jankiewicz, Stephen (2012), “A Dangerous Class: The Street Sellers of Nineteenth-century London”, Journal of Social History, 46(2), 391-415.

Olin-Wright, Erik (1978), Class, Crisis and the State. London: New Left Books.

Polanyi, Karl (2001), The Great Transformation: The Political and Economic Origins of Our Time. Boston, MA: Beacon Press [ed. orig.: 1944].

Sennett, Richard (1998), The Corrosion of Character: The Personal Consequences of Work in the New Capitalism. New York: Norton.

Shelley, Percy Bysshe (1819), “The Masque of Anarchy”. Disponível no site Poets' Graves, consultado a 28.04.2014, em http://www.poetsgraves.co.uk/Classic\%20Poems/ Shelley/the_mask_of_anarchy.htm.

Standing, Guy (2009), Work after Globalization: Building Occupational Citizenship. Cheltenham: Elgar.

Standing, Guy (2011), The Precariat - The New Dangerous Class. London: Bloomsbury [Versão traduzida O Precariado - A Nova Classa Perigosa. São Paulo: Autêntica]. Standing, Guy (2014), A Precariat Charter: From Denizens to Citizens. London: Bloomsbury. 